\title{
The "Fonds Georges Brohée" : a longstanding Belgian national initiative to stimulate research in hepatogastroenterology
}

\author{
I. Borbath ${ }^{1}$, R. Fiasse ${ }^{1}$, P. Van Hootegem² \\ (1) Service d'Hépato-gastroentérologie, Cliniques universitaires Saint-Luc, UCLouvain, Brussels, Belgium ; (2) Department of Internal Medicine, St.-Lucas General \\ Hospital, Brugge, Belgium.
}

\begin{abstract}
The Fonds Brohée/Brohée fund was created in 1964 at the initiative of 16 Belgian physicians, in the memory of Georges Brohée, the founder of the Belgian Society of Gastroenterology in 1928 and of its Journal in 1933, first published under the name "Le Journal Belge de Gastro-entérologie", then until today as "Acta Gastro-Enterologica Belgica". The goal of the Fonds is to stimulate research in the field of gastroenterology in Belgium, by awarding a young researcher ( $<40$ years) for an outstanding work in the clinical, translational or fundamental setting. Since 1966, 26 remarkable works have been awarded in various areas of interest in gastrointestinal diseases, whether in IBD, functional disorders, digestive oncology and, last but not least, hepatology. Since the recognition of their work, many of the awardees have become recognized for their expertise well beyond Belgium. Hopefully, the Foundation will continue to thrive and flourish after 55 years, as the members of its board and its healthy finances will allow to continue to promote and encourage high-quality research by young hepato-gastroenterologists in Belgium. (Acta gastroenterol. belg., 2021, 84, 91-94).
\end{abstract}

Keywords : Georges Brohée, Research prize, hepato-gastroenterology, Belgium.

The development of gastroenterology in Belgium and worldwide has been greatly stimulated by Georges Brohée (Ghlin 1887-Brussels 1957). Georges Brohée was born in the Borinage, at that time a prosperous mining and steel industry region in the French-speaking southern part of Belgium. He acquired his medical degree at the University of Brussels in 1912 (1).

Georges Brohée (Figure 1) was described by his contemporaries as an enthusiastic and somewhat authoritarian personality, an innovator, "impassionate with gastroenterology and almost obsessed with the idea of international meetings". His interest in international meetings began during his training as a surgeon in 1912 with Dr A. Depage in Brussels.

In 1920 he joined Drs. Duval and Roux at Vaugirard hospital in Paris for further training in surgery and in radiology of the gastrointestinal tract. Upon his return to Brussels, he founded a small independent clinic devoted to the practice of gastroenterology. Himself as a surgeon, worked in his clinic with a team including two internists and one radiologist, always recommending a multidisciplinary approach to gastro-intestinal diseases. He subsequently published some 50 papers (in French) about clinical problems, including gastroduodenal ulcer, gastric cancer, ulcerative colitis, Crohn's disease, and intestinal volvulus. In the ensuing years he co-founded

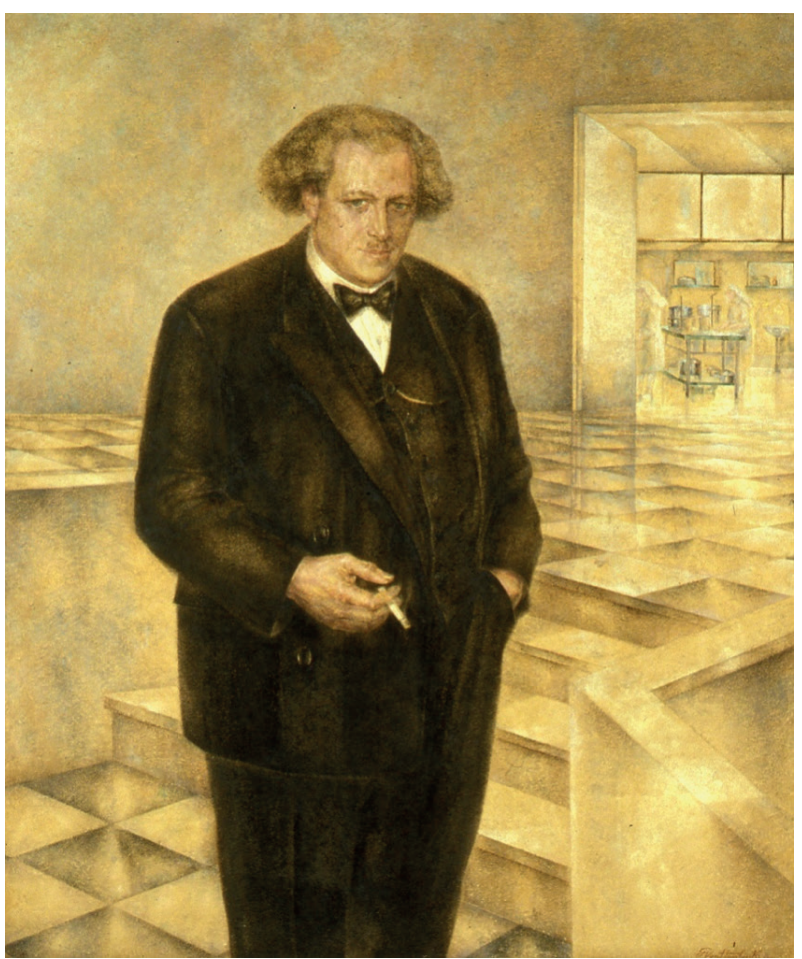

Figure 1. - Portrait of Georges Brohée, painted by Pierre Van Humbeeck, Musée de la Médecine de Bruxelles.

the Belgian Society of Gastroenterology in 1928 and its Journal in 1933, first published under the name "Le Journal Belge de Gastro-entérologie", then until today as "Acta Gastro-Enterologica Belgica" (for the complete story see (2)). From this vantage point he established contacts with gastroenterologists from Europe and worldwide, and he began his efforts to realise his dream of an International Society of Gastroenterology. G. Brohée mobilized his friends and correspondents and organized an International Congress in Brussels in 1935 under the presidency of Professor Jan Schoemaker of Holland. Two themes were selected for presentation: "gastritis" and "non-amoebic colitis". More than 600 physicians

Correspondence to: Prof. I. Borbath, Chef de Clinique, Service d'Hépatogastro-entérologie, Cliniques universitaires Saint-Luc, UCLouvain, 10 avenue Hippocrate, 1200 Bruxelles. 02/7642820.

Email : ivan.borbath@uclouvain.be

Submission date : 18/12/2020

Acceptance date : 14/01/2021 
from 35 countries were present. This was the very first international scientific meeting in gastroenterology, a distant predecessor of the present World congresses. On the day before the conclusion, on August 10, 1935, the Société Internationale de Gastro-entérologie (SIGE) was officially founded. The second International Congress was held in Paris, September 13-15, 1937 under the presidency of P. Duval. The two themes were : "Early diagnosis of stomach cancer" and "Acute chronic obstruction of the small bowel". The number of "national committees" had risen from 10 to 26 . The next congress was scheduled for July 1940 in London under the presidency of A. Hurst on the themes of "Ileitis" and "the relation between haematology and the stomach" but this meeting was cancelled by World War II. Four successive European Congresses were held : Lausanne (1948), Madrid (1950), Bologna (1952) and Paris (1954). Each congress focused on one or two main themes with invited commentators and a limited participation in the form of free papers related to these themes, and happened to be a friendly gathering of about 350 participants. In 1948, Dr Brohée was helpful to D. Bonorino Udaondo in establishing the Pan-American Association. A possible organizational plan linking local and national societies into a continental association and towards a World Federation gradually developed in his mind. Finally the first World Congress of Gastroenterology was held in Washington D.C. in 1958 (3-5). At this, the "Organisation Mondiale de Gastroentérologie" (OMGE) was born and Brohée's long held idea of a World Congress of Gastroenterology was finally realised, followed by subsequent OMGE (later on called World Gastroenterology Organisation - WGO) meetings in Munich (1962), Tokyo (1966), Copenhagen (1970), Mexico City (1974), Madrid (1978), Stockholm (1982), Sao Paolo (1986), Sidney (1990), Los Angeles (1994), Vienna (1998), Bangkok (2002), Montréal (2005), London (2009), Shangai (2013), Orlando (2017), Istanbul (2019). The next WGO congress will be held in Dubai in December 2021.

From 1954 on, G. Brohée was handicapped by illness and retired from the scene. He died in Brussels in 1957, poor and a little bit forgotten (1). He remained Editorin-Chief of the Acta Gastro-Enterologica Belgica until his death (2). The Journal he founded remains currently the only Belgian national Journal of gastroenterology, hepatology and digestive oncology indexed in PubMed. The scientific societies that have taken up the treasure, updated it (2) and are constantly preparing its future (6, 7) with the wish to maintain its vision of the dissemination of scientific knowledge.

In June 1964, the Governing Council of OMGE decided in Article 11 of the OMGE statutes, that "To commemorate Dr Georges Brohée, the founder of the first International Association of Gastroenterology, a Brohée Lecture will be delivered during each World Congress of Gastroenterology". Since then, every 4 years during the World Congress, the Georges Brohée Lecture is given by a distinguished member of the gastroenterological

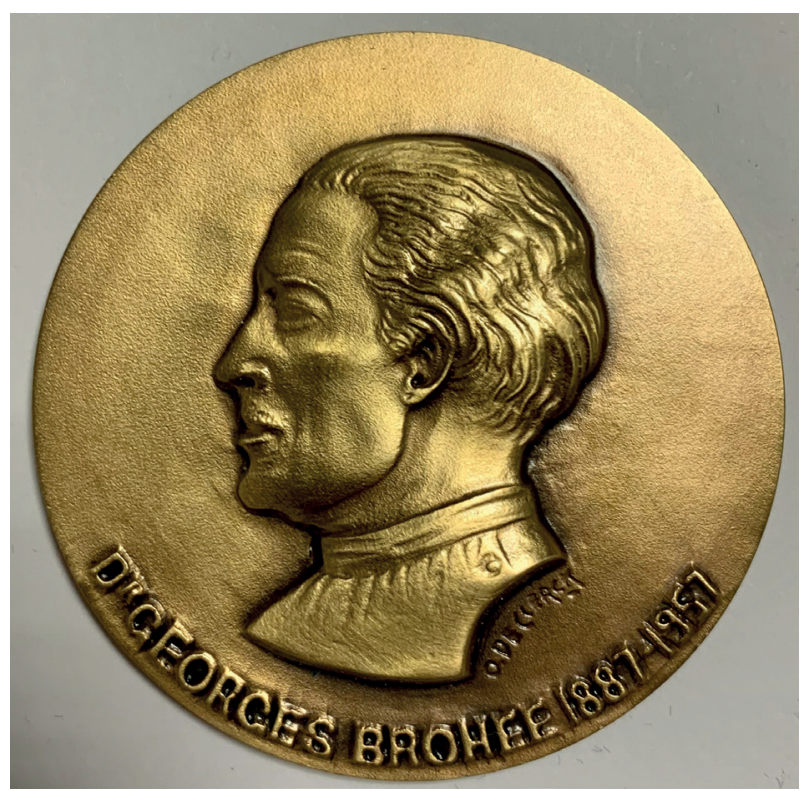

Figure 2. - Medal with the portrait of Georges Brohée, provided by the Belgian Brohée Foundation and given to each Brohée Prize awardee.

community. The lecturer receives a medal with the portrait of Brohée (Figure 2) on one side and the lecturers name on the other, provided by the Belgian Brohée Foundation.

Indeed, the $5^{\text {th }}$ November 1964, the Belgian Society of Gastroenterology created the Brohée Foundation ("Fonds Georges Brohée"), to promote research in gastroenterology in its broader sense, by creating a biennial Price awarded by an independent jury to a young investigator. Its statutes were published in the "Moniteur Belge", with founding members being Drs Marcel Brombart, Jean Daumerie, Léon Daumerie, Jan De Groote, Lucien Deloyers, Albert Froehlich, Jean Godart, Edouard Jacobs, Ernest Jacobs, Raymond Le Cluyse, Jean Massion, Léo Remouchamps, Liliane Ruyters, Jozué Vandenbroucke, René van Lerberghe and JeanPierre Weill. Sixteen physicians, 15 man (!), 11 working in Brussels, 4 in Flanders, and Dr Liliane Ruyters, working in Liège. The statutes of the ASBL/VZW were not modified until the $22^{\text {nd }}$ of December 2005, when 6 administrators were appointed: Dr Patrick Robberecht as president, Dr Martin Hiele as vice-president, Dr René Fiasse as secretary and treasurer, Dr Peter Michielsen and Jacques Devière as administrators. This was actually a formalization of the work done already for some years by the cited people, especially Dr René Fiasse. The official address of the Fonds Brohée was at the home of Mr Van Leemputten, who served already for years as administrative secretary and whose outstanding help has to be acknowledged. Later on, Dr Ivan Borbath took over the role of secretary (2013), Dr Martin Hiele became president (2011), Dr Edouard Louis became vice-president (2011) and Dr Peter Michielsen secretary (2017). Dr Devière and Dr Robberecht stepped out while Drs Sven Francque, Jean-Luc Van Laethem, Philippe Van 
Table. — List of the Brohée Prize awardees, from 1966 until 2019

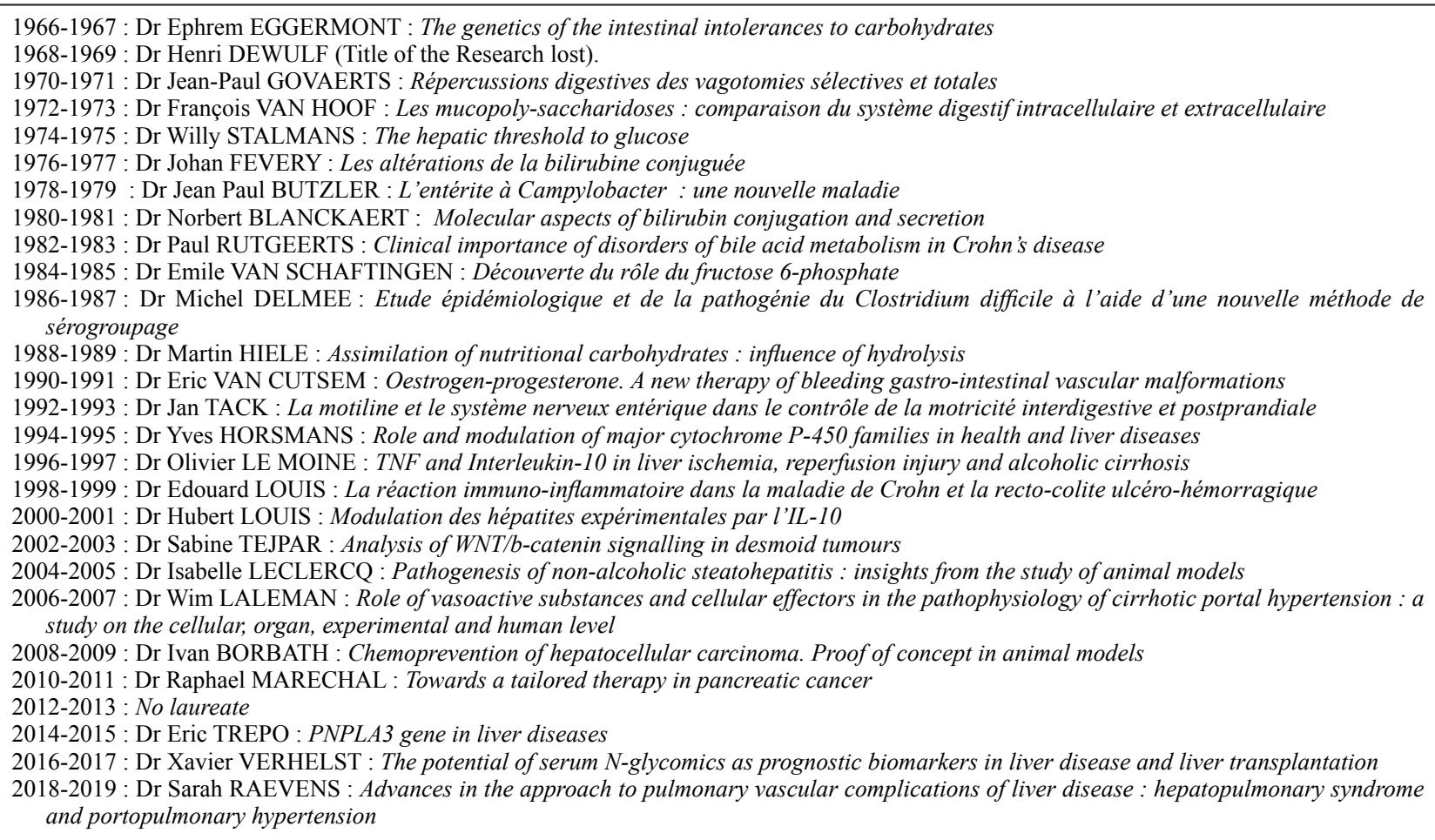

Hootegem and Daniel Urbain became administrators, until today. In 2017, the statutes were translated in Dutch and appeared in both national languages in the Moniteur Belge/Belgisch Staatsblad.

Since those early days in 1964, the Foundation developed as a ASBL/VZW with funds coming from a percentage of the benefits arising from the "European Congress of Gastroenterology" held in Brussels in 1964, the "Journées Francophones de Pathologies Digestives" held in Brussels in 1985 ; and finally from the "United European Gastroenterology week", held in Brussels in 2000 , and from generous donations. These funds allowed the biannual grant of $6500 €$ to be given, an amount that unfortunately had to be decreased to $5000 €$ after the 2008 subprime financial crisis and despite additional contributions to the fund capital from the various gastroenterological societies in Belgium.

Every other year, when no Prize is awarded, the Fonds Brohée invites a distinguished speaker to give the Brohée lecture during the Belgian Week of Gastroenterology.

Looking at the 26 winners of the Georges Brohée Prize (Table), it can be agreed on that the Brohée jury recognized early on many great scientists, whether in the field of IBD - Paul Rutgeerts (8), Edouard Louis (9) - ; functional disorders - Jan Tack (10), Hubert Louis (11) - ; digestive oncology - Eric Van Cutsem (12), Sabine Tejpar (13) - ; and hepatology - Yves Horsmans (14), Olivier Lemoine (15), Isabelle Leclercq (16), Wim Laleman (17). Only young endoscopists have not won the prize, although the field has been experiencing the revolution of therapeutic endoscopy. Probably just a matter of time before this will be corrected. Nevertheless, hepatology represents a very strong research area in Belgium : $11 / 26$ winners and $3 / 4$ winners in the last 10 years (18-20) performed outstanding work in the field of liver diseases.

In conclusion, the Fonds Brohée/Brohée fund continues to thrive and flourish after 55 years (!), as the members of its board - some of them former awardees -, the many people composing the Jurys over the years and its healthy finances allow to promote and encourage highquality research by young hepato-gastroenterologists in Belgium.

May this go on for long!

\section{References}

1. FIASSE R. Histoire de la Société Roryale Belge de Gastro-Entérologie, 2006 [Available from : https://www.srbge.be/histoire-de-la-srbge/.

2. MOREELS TG, FIASSE R, LANTHIER N. The history of Acta GastroEnterologica Belgica. Acta Gastroenterol. Belg., 2019, 82(1) : 57-61.

3. STANDAERT LO. History of ASNEMGE. Gastroenterol. Intern., 1993(6) : 180-5.

4. KIRSNER JB. The scientification of Gastroenterology during the 20th century (the 1994 Brohée Lecture in Los Angeles). Acta Gastroenterol. Belg., $1995, \mathbf{5 8}: 1-20$.

5. De GROOTE J. Van colloquia tot Vlaamse Vereniging voor Gastroenterologie : Flemish society of Gastroenterology, 2000.

6. LANTHIER N, MOREELS TG. The future of Acta Gastro-Enterologica Belgica. Acta Gastroenterol. Belg., 2019, 82(1) : 3-4

7. LANTHIER N, VANUYTSEL T. For better visibility of Acta GastroEnterologica Belgica. Acta Gastroenterol. Belg., 2020, 83(2) : 243-4

8. RUTGEERTS P, LOFBERG R, MALCHOW H, LAMERS C, OLAISON G, JEWELL D, et al. A comparison of budesonide with prednisolone for active Crohn's disease. N. Engl.J.Med., 1994, 331(13) : 842-5.

9. LOUIS H, LE Moine A, FLAMAND V, NAGY N, QUERTINMONT E, PAULART F, et al. Critical role of interleukin 5 and eosinophils in 
concanavalin A-induced hepatitis in mice. Gastroenterology, 2002, 122(7) : 2001-10.

10. TACK J. Antibiotic therapy for the irritable bowel syndrome. N. Engl. J. Med., 2011, 364(1) : 81-2.

11. LOUIS H, LE MOINE O, PENY MO, QUERTINMONT E, FOKAN D, GOLDMAN M, et al. Production and role of interleukin-10 in concanavalin A-induced hepatitis in mice. Hepatology, 1997, 25(6) : 1382-9.

12. VAN CUTSEM E, KOHNE CH, HITRE E, ZALUSKI J, CHANG CHIEN CR, MAKHSON A, et al. Cetuximab and chemotherapy as initial treatment for metastatic colorectal cancer. N. Engl. J. Med., 2009, 360(14) : 1408-17.

13. GUINNEY J, DIENSTMANN R, WANG X, DE REYNIES A, SCHLICKER A, SONESON C, et al. The consensus molecular subtypes of colorectal cancer. Nat. Med., 2015, 21(11) : 1350-6.

14. HORSMANS Y, BERG T, DESAGER JP, MUELLER T, SCHOTT E, FLETCHER SP, et al. Isatoribine, an agonist of TLR7, reduces plasma virus concentration in chronic hepatitis C infection. Hepatology, 2005, 42(3) : 72431.

15. LE MOINE O, LOUIS H, DEMOLS A, DESALLE $F$, DEMOOR $F$, QUERTINMONT E, et al. Cold liver ischemia-reperfusion injury critically depends on liver $\mathrm{T}$ cells and is improved by donor pretreatment with interleukin 10 in mice. Hepatology, 2000, 31(6) : 1266-74.

16. LECLERCQ I, SALIEZA, WALLEMACQ PE, HORSMANS Y, LAMBOTTE L. The monoethylglycinexylidide test does not correctly evaluate lidocaine metabolism after ischemic liver injury in the rat. Hepatology, 1997, 26(5) : 1182-8.

17. LALEMAN W, VAN LANDEGHEM L, VAN DER ELST I, ZEEGERS M, FEVERY J, NEVENS F. Nitroflurbiprofen, a nitric oxide-releasing cyclooxygenase inhibitor, improves cirrhotic portal hypertension in rats. Gastroenterology, 2007, 132(2) : 709-19.

18. TREPO E. Contribution of PNPLA3 gene to the natural history of liver diseases. Acta Gastroenterol. Belg., 2017, 80(1) : 43-51.

19. VERHELST X, GEERTS A, CALLEWAERT N, VAN VLIERBERGHE $\mathrm{H}$ The potential of glycomics as prognostic biomarkers in liver disease and liver transplantation. Acta Gastroenterol. Belg., 2019, 82(2) : 309-13.

20. RAEVENS SG, A. DEVISSCHER, L. VAN VLIERBERGHE, H. VAN STEENKISTE, C. COLLE, I. Recent advances in the approach to hepatopulmonary syndrome and portopulmonary hypertension. Acta Gastroenterol. Belg., 2021, 84 : 95-99. 